\section{Geography at the}

THE proceedings of Section E (Geography) opened with a paper by Lt.-Col. E. F. W. Lees on Aeronautical Maps. The rapid progress in aviation has necessitated the provision of special maps for airmen. The subject was considered by the International Convention for the Regulation of Aerial Navigation of October, 1919, at which some thirty States were represented. It was agreed that there shall be two series of international aeronautical maps : general aeronautical maps on Mercator's projection on a scale of $3 \mathrm{~cm}$. to I degree of longitude on the equator, and local aeronautical maps on a scale of $x: 200,000$. For the local maps no particular projection is laid downin many countries maps on this scale which could be adapted for the needs of airmen already exist. Col. Lees fully described the "British proposals, and explained that the divergences of view with the French and Belgian authorities as regards depiction of relief on the general maps, and some other points, have now been adjusted. The maps for the British Empire are now being constructed for the Air Ministry by the jeographical Section of the General Staff. Sir Charles Close criticised adversely the employment of Mercator's projection for the general maps. After the presidential address by Dr. D. G. Hogarth on the application of geography (NATURE, Sept. 22, p. I20), Miss A. M. B. Gillett read a paper on the historical geography of the black earth region of Central Russia. In the afternoon Capt. L. V. S. Blacker lectured on his travels in Turkistan and Khorasan from 1918 to 1920 .

The meetings on September 9 opened with a joint discussion with Section L on the origin of the Scottish people, opened by Sir A. Keith, followed by a joint discussion opened by Mr. G. G. Chisholm on the teaching of geography. This discussion, while directing attention to the weakness in geographical teaching in the higher forms of secondary schools, emphasised the need for specially trained teachers in the subject.

The morning of September I2 was devoted to a number of papers dealing with the geography of Edinburgh and district. Mr. F. C. Mears showed in a series of lantern slides how the medieval period of Edinburgh was a time of town-planning and civic organisation of industry and agriculture. The town in those days was laid out on a spacious plan, with a large market place on the top of the ridge. It was no exaggeration to say that Edinburgh was a garden city until the middle of the eighteenth century. Prof. P. Geddes said that the beauty of Edinburgh to-day was largely a survival, and that we were living amid the wreckage of a noble town. In no town were the natural beauties greater, but in no town had they been more completely overlooked and thrown away. $\mathrm{He}$ cited the complexity of the railways in Edinburgh as an outstanding example of muddle. New developments in the search for new industries threatened the town. Edinburgh might have its new industries and greater prosperity and at the same time conserve the beauties of its site if the industrial community were more cognisant of the development and evolution of the city, and understood its geographical setting and historical past. Mr. H. R. G. Inglis spoke of prehistoric Edinburgh, and described a collection of early plans of Edinburgh, lent by the Royal Scottish Geographical Society.

In a short note communicated by Mr. G. G. Chisholm, Mr. C. B. Fawcett directed attention to the great discrepancies which exist between the real population of many large urban areas and the census populations of the chief towns in those areas. In very few towns NO. 2709 , VOL. I08]

\section{British Association.}

is the city boundary thrown far enough out to include all the urban population, while in many cases the existence of densely peopled urban areas is ignored in the census return by distribution among several administrative areas.

On the morning of September ${ }_{3}$ Dr. Marion Newbigin opened the session with a paper on the Mediterranean city-state in Dalmatia. She pointed out that the early growth of independent or quasi-independent city-states was one of the most characteristic features of the Mediterranean area, a fact which suggested that such cities were a response to the geographical conditions. By an analysis of these conditions it was shown that they rendered possible local aggregations of population supported by intensive cultivation of the peculiar Mediterranean crops, and that further, the nature of these crops permitted the cultivators to dwell together in a walled town, placed on a site suitable for defence. The advantages and disadvantages of such sites were considered, especially the factors which limited growth in size. In Dalmatia, as elsewhere, the sites first chosen were not, as a rule, such as to facilitate either land or sea trade, but the limiting factors rendered it necessary that some supplement to the natural products should be found if the city were to attain any size. The significance of the sea-borne trade between the Mediterranean area and the Far East in promoting the prosperity of certain Mediterranean cities was pointed out. The lecturer then dealt more particularly with Dalmatian towns. Finally the constant recurrence of piracy, from Roman times onwards, on the Dalmatian shore was emphasised alike in connection with the medieval cities and with Italian policy to-day.

Lt.-Col. H. S. Winterbotham gave an account of the present position of the $\mathrm{I}: \mathrm{I}, 000,000$ map. The effect of the war on the progress of the map was curiously mixed. In some countries considerable pro gress was made, in others large areas were mapped on the desired scale, but not in strict conformity with the international resolutions, while in many cases the work was brought to a standstill. The provisional series of the I: I,000,000 map covering most of Europe and the Near East, for which the Royal Geographical Society and the Geographical Section of the General Staff were responsible, reached 89 sheets in close, if not complete, conformity with the international scheme. Of the international map, properly speaking, only 28 sheets are published, and I32 are in course of preparation. In Europe France, Italy, Denmark, Norway, Sweden, and Britain are each at work on several of their respective sheets. In India eight sheets have appeared, and several others are in hand. Japan and Siam are also at work. In Africa sheets are in hand of the Belgian Congo, Egypt, the Sudan, and South Africa. The United States has practically all its sheets in hand, and Canada has made a beginning. In South America great blocks in Brazil, Chile, and the Argentine are under way. Nothing has been done in Australia. Lt.-Col. Winterbotham concluded by showing that maps on $I$ : $I, 000,000$ scale exist for many other areas but not in the international style.

Miss R. M. Fleming read a paper on the geographic aspects of tradition. The share of physical and social environment in moulding tradition is easy to trace. For instance, the beauty of the Hebrew traditions was no doubt partly due to a leisurely life of wandering in vast spaces, and a familiarity with quiet solitudes. From the fact that they express the accumulated experience of past generations, an out- 
come of the hard conditions in which they grew, these traditions have been appreciated by the rest of the world. In studying stories of the origin of death one sees how the essential theme varies widely according to environment and experience. In certain instances Miss Fleming traced the adaptation to particular environments of a central theme. Lastly she showed how tradition grew and lingered around early trade routes.

The morning of September 13 closed with a paper by Mr. H. M. Spink on the distribution of commercial timber on the Pacific Coast of North America. In the afternoon Mr. A. W. Grabham lectured on his recent experiences in a journey from Lake Tana to Roseires, paying spècial regard to the water supply. The work of Section, $E$ included visits to Leith docks and the cartographical works of Messrs. J. Bartholomew and Co., and Messrs. W. and A. K. Johnston.

\section{An Automatic Recorder of Smoke Pollution.}

$\mathrm{I}$ an article on "London Air" in the Times of 1 August 23 Sir Napier. Shaw directed attention to the clear atmosphere which was such a noticeable feature in all industrial centres during the recent coal strike. The article in question is, however, chiefly interesting for its description of an ingenious self-recording contrivance invented by Dr. J. S. Owens for the Atmospheric Pollution Committee of the Meteorological Office, which registers hourly the amount of solid atmospheric impurities. A fixed volume of air is aspirated through a small disc of filter-paper, and from the depth of shade the amount of deposit is estimated by comparison with discs of standard shades. In London the notably dirty period is from 9 a.m. to 5 p.m., i.e. the business hours of the day. The greatest impurity, is, of course, in winter, that of a May day being about one-quarter that of a November day. The day impurity in May is of the same order as the night impurity in November. The instrument should prove useful in detecting any noticeable improvement or otherwise in the amount of solid impurities in different towns. Although Sir Napier Shaw states that these measurements of the Committee "are noteworthy as the first series of systematic observations of the pollution of the air of London and other centres of population," he has apparently overlooked the fact that a complete series of records was made in Leeds some years previously, in the course of which it was clearly established not only that the domestic fireplace is responsible for much the larger proportion of the soot emitted from burning coal, but also, more important still, that this domestic soot is much more highly contaminated with tar than that from factory chimneys. In his reference to possible means of smoke prevention from domestic fireplaces, Sir Napier Shaw makes no reference to the carefully considered report which was published in the autumn of last year by the Committee on Smoke Abatement appointed by the Ministry of Health. It was there pointed out that the ordinary open kitchen range was wasteful and inefficient, and the Committee strongly insisted on the advantage of gas-cookers where gas was available. Low-temperature coke was also advocated whenever the right sort of material could be placed upon the market-a desideratum not yet attained. But there are numerous forms of improved ranges in which coke and anthracite can be burned much more economically than in the old open range, and, of course, without the emission of smoke. It now remains for the Ministry of Health to bring pressure to bear on those engaged upon Government building schemes to adopt these recommendations. It has a unique opportunity for setting an example in atmospheric purification.

\section{University and Educational Intelligence.}

Berast.-Dr. J. K. Charlesworth has been appointed professor of geology : in the Queen's University. Until the present session the head of the department of geology was a lecturer, but, owing to the importance of the subject, the Senate has raised the lectureship to a professorship.

Birmingham.-The University has now been in existence for twenty-one years, and in commemoration of the event the Council and Senate have invited a large number of friends of the University to a conversazione on October 7, at which the Edgbaston buildings will be open to inspection.

London.-Mr. A. E. Webb has been appointed senior assistant in the department of civil and mechanical engineering of University College. Mr. C. D. Burns has been appointed lecturer in philosophy at Birkbeck College.

In connection with the department of philosophy of King's College a course of ten public lectures will be given by Prof. H. Wildon Carr on "The Modern Scientific Revolution and its Meaning for Philosophy ", on Tuesdays at 5.30 , beginning on October $\mathrm{r}$. In connection with the faculty of psychology a similar number of lectures on "Psychology and Psychotherapy "' will be given by Dr. W. Brown on Tuesdays at 5.30 beginning on October 18 .

St. Andrews.-Dr. W. J. Tulloch, lecturer in bacteriology in the University, has been appointed to be the first professor of the chair of bacteriology, established and approved by his Majesty in Council on June 27 last.

The Salters' Institute of Industrial Chemistry has awarded fellowships for post-graduate study in the laboratories of the institute to Messrs. J. A. Gentle, F. Raymond Jones, S. J. Saint, and F. W. Turner. Scholarships have been awarded to Messrs. B. G. Banks and L. G. Laws.

Post-GRaduATe research scholarships in naval architecture of $25 \mathrm{ol}$. a year each have been awarded by the Institution of Naval Architects to Mr. H. W. Nicholls, of the Royal Naval College, Greenwich, who will carry out research on the vibration of ships, and Mr. W. R. Andrew, of Liverpool University, who will investigate the behaviour of ships at sea during a longdistance voyage, and report on shipbuilding and conditions abroad.

Some bequests of noteworthy importance are made in the will of Mrs. L. A. Stuart, widow of Prof. James Stuart. Cambridge University Local Lecture Syndicate will receive a sum of $5000 l$. for a James Stuart endowment in memory of Prof. Stuart's work in founding the University Extension Lectures. In addition, Trinity College, Cambridge, is to receive $2000 l$., which it is suggested should be applied to the establishment of Stuart scholarships or studentships, and a similar sum is bequeathed to Newnham College, Cambridge.

ON Tuesday, October II, a dinner in honour of Prof. J. C. Philip will be held in the Imperial College Union, Prince Consort Road, South Kensington, at 7 for 7.30 p.m., when Sir William A. Tilden will present to him an illuminated address and gifts from his colleagues and students to express deep appreciation of Prof. Philip's active interest in every movement for the advancement of the Royal College of Science during his service, now twenty-one years, on the chemical staff of the college. The chair will be taken by Sir Richard Gregory, president of the Royal College of Science Association. NO. 2709 , VOL. IO8] 